\title{
Nurse Practice License Policy (Study on the Implementation of the Nurse Practice License Policy in Lamongan Regency)
}

\author{
Dadang Kusbiantoro $\quad$ Arif Darmawan Joko Widodo \\ Doctoral Administration Study Program Faculty of Social and Political Sciences 17 Agustus 1945 University of \\ Surabaya. Semolowaru 45 street,Surabaya
}

\begin{abstract}
The implementation of nursing practice is regulated in Law No. 38 of 2014 concerning Nursing. Nurses who work must have a Nurse Practice License, which is abbreviated as SIPP (Surat Izin Praktik Perawat). Nurses are required to have SIPP1 to work in health care agencies and are required to have SIPP2 if they practice independent nursing. Researchers noticed some problems related to the license policy. The purpose of this study was to analyze and develop a model for implementing a nurse practice license policy in Lamongan district. The researcher used George Edward III's theory of public policy implementation. The research method used was descriptive qualitative design with a phenomenological approach. The source of data were obtained from informants and document studies. Informants in this study were policy implementers, namely from professional organizations, health offices, licensing offices and policy recipients, namely nurses. The data were collected through in-depth interviews and observations. The results showed that the communication factor between policy implementers was running well, but communication between implementers and policy recipients was still not optimal. In the resource factor, there were nurses with different educational backgrounds and different levels of competence. The disposition factor showed a commitment from the local government to support the implementation of the nurse practice license policy in Lamongan district. Regarding the bureaucratic structure, there were already local regulations governing the policy for nurse practice license.Supporting factors for the implementation of the nurse's practice license policy were in the form of laws and regulations regarding nursing. Inhibiting factors are gray areas in nursing practice, community perceptions of nurse practices, nurse competence according to the type of nurse and educational background.In conclusion, the implementation of the nurse practice license in Lamongan Regency has been running but not optimal. The researchers recommend an evaluation towards the nurse's practice license policy and carry out research findings.
\end{abstract}

Keywords: Policy, Nurse Practice License

DOI: $10.7176 / \mathrm{PPAR} / 10-11-03$

Publication date: November $30^{\text {th }} 2020$

\section{INTRODUCTION}

\section{Background of the Study}

Health as a human right and is the responsibility of the Government and all elements of society, must be realized in the form of providing various health efforts through the implementation of quality and affordable health development. Human rights in the health sector must be realized through health development aimed at improving the welfare of individuals, families and communities by instilling healthy living habits. The implementation of health development is realized through the provision of health services supported by professional health resources, both health workers and non-health workers. Nurses in carrying out health services act as administrators of nursing practice, providers of nursing care, counselors for clients, managers of nursing services, and nursing researchers. Nursing services provided by nurses are based on knowledge and competence in the field of nursing science which is developed according to client needs, scientific developments, and the demands of globalization.

Article 63 paragraph (4) of Law No. 36 of 2009 concerning Health states that the implementation of treatment and/or treatment based on medical science or nursing science can only be carried out by health workers who have expertise and authority. Article 62 paragraph (1) of Law Number 36 Year 2014 concerning Health Workers states that health workers in carrying out their practice must be in accordance with the authorities based on their competencies, and further in paragraph (2) it is explained that certain types of health workers who have more than one level of education has professional authority in accordance with the scope and level of competence. Article 16 paragraph (4) of Law No. 38 of 2014 concerning Nursing states that work competency standards are prepared by the Nursing Professional Organization and Nursing Council and set by the Minister of Health.

Nursing services are a form of professional service that is an integral part of health services based on nursing knowledge and tips for individuals, families, groups or communities, both healthy and sick. The focus of nursing is the client's response to disease, treatment, and the environment. The fundamental responsibility of the nurse is to improve health, prevent disease, restore and reduce suffering.

Health services, including nursing services, must be carried out in a responsible, accountable, quality and safe 
manner by nurses who have obtained registration and permission to practice. Nursing practice as a tangible form of nursing service is carried out independently, based on the delegation of authority, assignments under certain limitations, and assignments in emergencies or collaboratively.

Nurses are required to have a Nurse Registration Certificate (STRP) in carrying out nursing practice. To obtain STRP, nurses must have a certificate of competence or professional certificate and other requirements in accordance with the provisions of the applicable laws and regulations. The STRP is valid for 5 years. STRP is obtained in accordance with the provisions of laws and regulations and if it has expired, it can be extended as long as it meets the requirements. Nurses who practice nursing are required to have a Nurse Practice License (SIPP). SIPP is given to nurses who already have STRP. The SIPP is issued by the district or city government. This SIPP applies to one health service facility. SIPP is valid as long as the STRP is still valid and can be extended again as long as it meets the requirements. Nurses can only have a maximum of 2 (two) SIPPs, where the second SIPP application must be done by showing the first valid SIPP.

Along with the increase in population, every year there is also an increase in the need for health personnel, one of which is nurses. Nurses are health workers with the largest number and needs among other health professions. The ratio of nurses to 100,000 Indonesians in 2014 was 94.07 nurses per 100,000 populations; in 2015 it decreased to 87.65 nurses per 100,000 populations. The ratio of nurses in 2016 nationally was 113.40 per 100,000 populations. This is still far from the target ratio of nurses set in 2014 of 158 nurses per 100,000 populations, even far from the 2015-2019 Ministry of Health's Strategic Plan target of 180 nurses per 100,000 populations. Based on data from the Health Human Resources Development and Empowerment Agency (BPPSDMK), the percentage of nurses is the largest among other health professions, namely $29.66 \%$ of all health personnel recapitulation in Indonesia as of December 2016.

Based on the education level classification of the total number of nurses in Indonesia, $77.56 \%$ are not graduated from nurse profession, but from diploma or bachelor without professional education. Professional nurses are those who graduated from bachelor of nursing with 1 year of professional education as many as $10.84 \%$ while those who graduated from health nursing school (SPK) was 5.17\%. Meanwhile, specialist nurses were only $6.42 \%$. The number of nurses in Indonesia in 2019 reached 345,508 people. The largest distribution is in East Java as many as 48,164, Central Java 45,107, West Java 35,747 and DKI Jakarta 26,950, while the lowest distribution is in West Sulawesi, as many as 1,550 people (BPS, 2020).

The number of nurses in Lamongan Regency is 2,297 people. Based on the educational background of nurses in Lamongan Regency, there are 5 SPK graduates, 1,360 diploma graduates, 902 professional nurses, and 30 master degree graduates. Based on gender, 1,080 nurses are men while 1,217 nurses are women. Based on the workplace, 1,163 are working in government agencies while the others are working in private agencies. Nurses who carry out independent practices and have SIPP in Lamongan Regency in 2020 are 646 people.

Some problems in obtaining nurse practice license are: 1). every nurse who works in health services is required to have SIPP 1. If the nurse opens an independent practice, the nurse must have SIPP 2. There are still nurses who do not have SIPP but have already conducted independent practice. 2). some nurses whose SIPP are inactive do not renew it due to ineligible requirements. 3). there are some nurses whose SIPP still stated at the old workplace, even though they had moved to a new health service. This shows that there are still problems in the implementation of Nurse Practice License policy.

To ensure the protection of the community as recipients of nursing services and to ensure the protection of nurses as providers of nursing services, comprehensive nursing arrangements are required to regulate in laws. The Law on Nursing provides legal certainty and legal protection as well as to improve, direct and organize various legal instruments that regulate the administration of nursing and nursing practice that is responsible, quality, and safe in accordance with developments in science and technology. This regulation contains type of nurse, nursing higher education, registration, practice license, and re-registration, nursing practice, rights and obligations of nurses, rights and obligations of clients, institutions related to nurses (such as professional organizations, colleges and councils), development, coaching, and supervision for nurses and administrative sanctions.

The regulations related to nursing arrangements include Law of the Republic of Indonesia Number 36 of 2009 concerning Health. Law of the Republic of Indonesia Number 36 of 2014 concerning Health Workers. Law of the Republic of Indonesia Number 38 of 2014 concerning Nursing. Regulation of the Minister of Health of the Republic of Indonesia Number 26 of 2019 concerning Implementation Regulations of Law Number 38 of 2014 concerning Nursing, as well as Decree of the Minister of Health of the Republic of Indonesia Number HK.01.07 / MENKES / 425/2020 concerning Nurse Professional Standards.

\section{Research Objectives}

1. To analyze the implementation of nurse practice license policy in Lamongan regency

2. To analyze and formulate a model for implementing nurse practice license policy in Lamongan Regency 


\section{RESEARCH METHODS}

The method used in this research was descriptive qualitative. The approach was a phenomenological approach. This research was focused on how the implementation of the nurse's practice license policy carried out along with the factors which affected it. Then, the research was directed to create a model in the implementation of the best Nursing Practice Permit Policy. Primary data were obtained through interviews with informants and field observations in the form of field notes. Secondary data were in the form of several documents including statutory regulations, snippets of data from social media, letter archives and so on. The informants of this research came from the Nurse Professional Organization in Lamongan Regency, the Health Office, the Licensing Service, Independent Practicing Nurses, Non-Self Practicing Nurses, and the Community. Data in the form of documents was the applicable laws and regulations. The data were collected through in-depth interview and observation. Then, the data were analyzed using qualitative descriptive analysis. The triangulation techniques used in this study were source triangulation, method triangulation, and theory triangulation.

\section{RESEARCH RESULTS AND DISCUSSION}

Since the issuance of Law Number 38 of 2014 concerning Nursing and Regulation of the Minister of Health number 26 of 2019 concerning regulations for the Implementation of Law Number 38 of 2014 concerning Nursing, nurses have gradually begun to control administratively related to the management of nursing practice license including the implementation of independent nursing practices. .

Furthermore, in carrying out nursing practice nurses are required to have a Nurse Practice License. Nurse Practice License is a written evidence provided by the district/city government to nurses as giving authority to carry out nursing practice. Nurse Practice License is given to nurses who already have a Nurse Registration Certificate (STRP). The SIPP is issued by the district or city government. This SIPP is only valid for 1 health service facility. SIPP is valid as long as the STRP is still valid and can be extended again as long as it meets the requirements. Nurses can only have a maximum of 2 (two) SIPP. Applications for the second SIPP must be submitted by showing the first valid SIPP. The number of nurses in Lamongan Regency who already had SIPP 1 was 2297 nurses, of that number who already had SIPP 2 were 646 nurses $(28.12 \%)$. This showed that there were still many nurses in Lamongan Regency who did not carry out independent nursing practices even though Law No. 38 of 2014 concerning nursing had stated that a nurse may open nursing practice independently.

Supporting factors for the implementation of policies for managing a license to practice nursing in Lamongan Regency are as follows:

1. Law of the Republic of Indonesia Number 36 of 2009 concerning Health

2. Law of the Republic of Indonesia Number 36 of 2014 concerning Health Workers

3. Law of the Republic of Indonesia Number 38 of 2014 concerning Nursing

4. Presidential Regulation Number 97 of 2014 concerning Implementation of One Stop Services

5. Regulation of the Minister of Home Affairs of the Republic of Indonesia Number 138 of 2017. Concerning the Implementation of Regional One Stop Services.

6. Regulation of the Minister of State Apparatus Empowerment and Bureaucratic Reform of the Republic of Indonesia Number 23 of 2017 concerning the Implementation of Public Service Malls

7. Regulation of the Minister of Health of the Republic of Indonesia Number 26 of 2019 concerning Implementation Regulations of Law Number 38 of 2014 concerning Nursing

8. Decree of the Minister of Health of the Republic of Indonesia Number HK.01.07 / MENKES / 425/2020 concerning Nursing Professional Standards.

9. East Java Governor Regulation No. 4/2010 concerning Village Health Lodges in East Java

10. Lamongan Regency Regulation Number 9 of 2018 concerning Licensing and Implementation of Independent Nurse Practices.

Meanwhile, some inhibiting factors in the implementation of nurse practice license in Lamongan district were as follows: 1). The problem of Nurse Gray Area, 2). Perceptions of complex licensing services, 3). Public perception about nurses and doctors, 4). Types of nurses with various educational backgrounds with different scope of authority, 5). Nurse competence, 6). Increasing number of health service facilities.

To facilitate coordination related to independent nursing practice, including the mechanism for obtaining practice nurses license in Lamongan Regency, an Independent Practice Nurse Communication Forum has been established. This forum was established in 2018 and has provided services in the form of consultation and facilitation of all problems related to independent nursing practice. Lamongan District Health Office usually conducts coaching in the form of a coordination meeting with representatives of members of other professional organizations, for example IDI, IBI, IAI, IFI and several other professional organizations. 
Table 1. Findings Matrix for the implementation of a nurse practice license in Lamongan Regency

\begin{tabular}{|c|c|c|}
\hline No & Factors & Findings \\
\hline 1 & Communication & $\begin{array}{l}\text { There was still a wrong community perception about nurses' independent practice. } \\
\text { There was still a lack of understanding from the public and other professions } \\
\text { regarding laws that allowed and regulated the practice of independent nursing. }\end{array}$ \\
\hline 2 & Source & $\begin{array}{l}\text { There were still nurses who worked in health care facilities but did not have Nurse } \\
\text { Practice License. } \\
\text { There were more vocational nurses than professional nurses. Vocational nurses with } \\
\text { a longer working period were sometimes better than professional nurses who had } \\
\text { just started working. } \\
\text { An Independent Practice Nurse Communication Forum was formed in Lamongan } \\
\text { Regency. }\end{array}$ \\
\hline 3 & Disposition & $\begin{array}{l}\text { There was a commitment from the policy implementer to expedite the process of } \\
\text { obtaining Nurse Practice License with a length of service around } 1 \text { up to } 3 \text { weeks. } \\
\text { There were efforts to provide guidance to manage independent nurse practice license } \\
\text { with other professional organizations. }\end{array}$ \\
\hline 4 & $\begin{array}{l}\text { Bureaucratic } \\
\text { Structure }\end{array}$ & $\begin{array}{l}\text { Regional regulations governing independent practice of nurses already existed, but } \\
\text { a Regent Regulation on independent practice of nurses did not exist. }\end{array}$ \\
\hline
\end{tabular}

Source: Researcher Data Processing, 2020

Development of health is aimed at increasing awareness, willingness and ability to live a healthy life for everyone in the context of realizing an optimal degree of health as an element of welfare as referred to in the Preamble to the 1945 Constitution of the Republic of Indonesia. Health as a human right must be realized in the form of providing various quality and affordable health services for the community. Nursing service is a form of professional service that is an integral part of health services based on nursing knowledge and tips aimed at individuals, families, groups, or communities, both healthy and those with physical, mental, social and spiritual health problems in various settings. Nursing service is a form of professional service, therefore competent human resources are needed.

Spencer \& Spencer (1993) stated that "Competency is the underlying characteristic of an individual that is causally related to criterion-reference to effective and / or superior performance in a job or situation". In other words, competence is a basic characteristic of a person related to effective and/or superior performance criteria in a particular job and situation. Furthermore, Spencer \& Spencer explained that competence is an underlying characteristic because it is deep and inherent part of a person's personality and can predict various situations and types of work. It is said to be causally related because competence causes or predicts behavior and performance. It is said to be criterion-referenced, because competence really predicts who is performing well or poorly, based on certain criteria or standards (Yulianto Kadji, 2015).

In line with the above statements, Robbins (2001) stated that an individual's capacity in carrying out his job duties is based on intellectual and physical abilities (intellectual and physical abilities). Robbins called competence as an ability, which is the capacity of an individual to do various tasks in a job. Furthermore, it is said that individual abilities are formed by two factors, namely intellectual abilities and physical abilities. Intellectual ability is the ability needed to carry out mental activities while physical ability is the ability needed to perform tasks that require stamina, dexterity, strength, and skills (Yulianto Kadji, 2015).

According to Spencer and Spencer (1993), competence is formed by five things, namely motives, traits, selfconcept, knowledge, and skills. Motives and character are core competences or central competencies, while knowledge and skills are referred to as individual competences which are "intent" which encourage the use of knowledge and skills. In contrast to Spencer's conception, Goleman (1998) states that a person's competence is closely related to their intelligence. Therefore, a person's competence can basically be grouped into two, namely personal competence and social competence. Personal competence includes self-awareness, self-regulation, and motivation. Meanwhile, social competence includes empathy and social skills (Yulianto Kadji, 2015).

To prepare quality resources, it is necessary to have nurse competency standards in order to create a positive reciprocal relationship. Nursing competency standards can be used by educational institutions, health services, training institutions, nursing associations and associations, and the government according to their respective roles and functions. The purpose of nurse competency standards is to provide assurance to the community in getting services in the form of nursing care by competent nurses. While the objectives of the nurse competency standard are: 1). Explain the standard background of nurse competence, 2). Explain the legal basis for nurse competence standards, 3). Explain the benefits of nurse competency standards, 4). Explain 5 (five) areas of nurse competence 
based on the type of nurse, 5). Describe nursing problems and skills for each type of nurse.

The benefits of standard competence for nurses are the availability of documents to get an overview of the competencies obtained during education, as a guide in the implementation of nursing practice, and as a measure of self-ability. For educational institutions, competency standards are useful as a reference in curriculum preparation and teaching development, encouraging consistency in conducting education and training, and establishing testing criteria and testing measuring instruments. For the government/users, competency standards are useful to be used as a reference in employee planning, recruitment and selection, appointment or placement in positions, job appraisals, remuneration/incentives and disincentives as well as educational and training needs in fulfilling the improvement/development of nurse competencies. For professional organizations, competency standards serve as a reference for managing membership, organizational governance, designing and implementing sustainable professional development programs in accordance with the needs of nursing services and as a reference for assessing nurse competencies. For the community, competency standards are useful as a reference for obtaining the characteristics of the nursing profession that can meet the needs of nursing services in Indonesia.

Based on the Decree of the Minister of Health of the Republic of Indonesia Number HK.01.07/MENKES/425/2020 concerning Nursing Professional Standards. The standard of nurse competence consists of:

1. Competence Area. Relating to the area of nurses where the competence of nurses includes knowledge, attitudes and skills (soft and hard skills). The nurse competency framework is grouped into 5 competency areas. This area is in accordance with the 5 Domains of the ASEAN Nursing Common Core Competencies, namely: 1). Ethical, legal and culturally sensitive practices 2). Professional nursing practice 3). Leadership and management 4). Education and research, 5). Personal and professional quality development.

2. Competency Components. The components of nurse competency include:

1) Ethical, legal and culturally sensitive areas of practice. Competence components consist of ethical, legal, cultural sensitivity

2) Professional nursing practice area. The competency components are nursing care management and quality of nursing practice

3) Leadership and management area. The competency components consist of the leadership and management of nursing services

4) Education and research areas. The competency components consist of education and research

5) Development area of personal and professional quality. The area of competence consists of professional development through continuing education and the development of science and technology.

Based on the results of the analysis and discussion of implementation, supporting factors, inhibiting factors, expected models, research findings, practical and theoretical implications are faced with the theory of implementation of the policy of practice license for nurses in Lamongan Regency using George Edwards III's theory, that competence factors are needed in implementation nurse practice permit policy. The success of a specific public policy is determined by factors of communication, resources, disposition, bureaucratic structure and competence.

\section{CLOSING}

\section{Conclusion}

1. The implementation of the Nursing Practice License Management Policy in Lamongan District is not yet optimal.

2. The supporting factor for the implementation of the Nurse Practice License Policy in Lamongan Regency is the joint commitment among the implementers of Nurse Practice License policy. The inhibiting factors are the competence of nurses with varying educational backgrounds and scope of authority.

3. The expected model from the research on the implementation of the Nursing Practice License Policy in Lamongan Regency lies in the human resource competence of nurses.

\section{Recommendation}

1. The local government of Lamongan Regency needs to evaluate nurse practice license policy, including the ownership of SIPP1 for nurses who work in health services and SIPP2 for nurses who carry out independent nursing practices.

2. Supporting factors can be followed up by setting up the online SIPP management mechanism according to regulations, while the inhibiting factor in the form of Human Resources at work must use the principles of nursing practice. Thus, it is not only the number that manages and owns SIPP2, but rather refers to the quality of nursing practice services.

3. The local government of Lamongan Regency should give priority to Nurse Practice License Policy according to the model of the results of this study and immediately issue a Regent Regulation which 
regulates the implementation of independent nursing practices as guidelines for implementing nursing practices.

\section{REFERENCES}

Kozier, Erb, (2000). Fundamental Of Nursing : Concept Theory and Practices. Philadelphia : Addison Wesley Ngesti W Utami, dkk, (2016). Etika Keperawatan dan Keperawatan Profesional. Jakarta : Kementrian Kesehatan Republik Indonesia

Pengurus Provinsi PPNI Jawa Timur, (2010). Panduan Organisasi Profesi Persatuan Perawat nasional Indonesia (PPNI). Surabaya : PPNI jawa Timur

Asmadi, (2008). Konsep dasar Keperawatan. Jakarta : EGC

Burhan, Bungin, (2013). Metodologi Penelitian Sosial \& Ekonomi. Jakarta : Kencana Prenada Media Group

Creswell, John W, (2009). Research Design, Qualitative, Quantitative, And Mixed Methods Approaches. London : SAGE

Dunn, William N . (2003). Pengantar Analisis Kebijakan Publik. Yogyakarta : Gadjah mada University press

Edi Suharto. (2010). Analisis Kebijakan Publik Panduan Praktis Mengkaji Masalah Dan Kebijakan Sosial. Bandung: Alfabeta

La Ode Jumadi Gaffar, (1999). Pengantar Keperawatan Profesional. Jakarta : EGC

Joko Widodo. (2016). Analisis Kebijakan Publik Konsep dan Aplikasi Analisis Proses Kebijakan Publik. Malang : Media Nusa Creative

Tachjan, (2006). Implementasi Kebijakan Publik. Bandung: AIPI Bandung OUSLIT KP2W LEMLIT UNPAD

Taylor, Lilis L Mone. (1999). Fundamental Of Nursing. Lipincott

Yulianto, Kadji, (2015). Formulasi dan Implementasi Kebijakan Publik. Kepemimpinan dan Perilaku Birokrasi Dalam Fakta Realitas. Gorontalo : Universitas Negeri Gorontalo Press.

\section{Laws and regulations}

Law of the Republic of Indonesia Number 36 of 2009 concerning Health (State Gazette of the Republic of Indonesia of 2009 Number 144, Supplement to the State Gazette of the Republic of Indonesia Number 5063)

Law of the Republic of Indonesia Number 36 of 2014 concerning Health Workers (State Gazette of the Republic of Indonesia of 2014 Number 298, Supplement to the State Gazette of the Republic of Indonesia number 5607).

Law of the Republic of Indonesia Number 38 of 2014 concerning Nursing (State Gazette of the Republic of Indonesia of 2014 Number 307, Supplement to the State Gazette of the Republic of Indonesia Number 5612)

Presidential Regulation Number 97 of 2014 concerning Implementation of One Stop Services (State Gazette of the Republic of Indonesia of 2014 Number 221)

Regulation of the Minister of Administrative and Bureaucratic Reform of the Republic of Indonesia Number 23 of 2017 concerning the Implementation of Public Service Malls (State Gazette of the Republic of Indonesia of 2017 Number 1387)

Regulation of the Minister of Health of the Republic of Indonesia Number 26 of 2019 concerning Implementation Regulations of Law Number 38 of 2014 concerning Nursing (State Gazette of the Republic of Indonesia of 2019 Number 912).

Decree of the Minister of Health of the Republic of Indonesia Number HK.01.07 / MENKES / 425/2020 concerning Nurse Professional Standards.

East Java Governor Regulation Number 4 of 2010 concerning Village Health Lodges in East Java

Lamongan Regency Regional Regulation Number 9 of 2018 concerning Licensing and Implementation of Independent Nurse Practices 